\title{
Coups and conflict
}

Essentially, the Australian media is only interested in covering the Pacific if it involves a coup, a conflict or a natural disaster. The only positive stories are primarily related to tourism. Part of this media attitude towards the Pacific stems from recent history.

\section{By ANTHONY MASON}

IN THE aftermath of the 1987 coup in Fiji, New Zealand television coverage reportedly showed tanks driving through tropical streets, juxtaposed with footage of the Bank of New Zealand branch in Suva lying in ruins. As Peter Thomson suggests in his book, Kava in the Blood, the foreign editor putting together this story did not realise that there were no tanks in Fiji. The footage of the tanks must have come from Africa. And the footage of the bank in Suva simply showed the demolition of the old building prior to the reconstruction of the new branch, some time before the coup.

Such deliberate misconstruing of the facts, especially in visual form, is both outrageous and frightening. However, it clearly demonstrates the potential the media has to influence wider understanding of a country or culture, particularly in at time of crisis.

My article looks at the kind of coverage Australians are getting about the Pacific, why we are getting this kind of coverage, what is the impact of it, and whether anything can be done to improve the situation.

I want to start by first explaining my position. After completing my degree in journalism at the University of Canberra, I have worked as a journalist and editor for the last ten years. In that time, I have worked at a small country newspaper, an English language radio station in Moscow, on a weekly Canberra newspaper, and as the editor of the University of Canberra newspaper, Monitor. At the end of last year, I gave up work to study full time. 


\section{ANTHONY MASON}

In the middle of last year, I was approached by Satendra Nandan to edit a book of his writings, Fiji: Paradise in Pieces. Since then, my understanding of the situation in Fiji, and more generally in the Pacific, has grown immensely. As my learning curve increased rapidly in a short period of time, I couldn't help wondering why I knew so little about Fiji and the Pacific.

As a journalist, and given my interest in how the media operates, I soon realised that for some reason the Pacific was not a region which seemed to interest the media. As a result, I began to look into the kind of coverage Australians get about the Pacific.

\section{What kind of coverage is Australia getting?}

Essentially, the Australian media is only interested in covering the Pacific if it involves a coup, a conflict or a natural disaster. The only positive stories are primarily related to tourism. Go to the search engine of the online version of any Australian broadsheet newspaper and type in the words Fiji and coup. A long list of stories will appear. Type in Fiji and tourism, and you will also get many stories. You might also get a few stories if you typed in Fiji and sport, or Fiji and rugby. But type in Fiji and art, or Fiji and writing, or Fiji and history, and the results are disappointing.

Part of this media attitude towards the Pacific stems from recent history. The Australian media first began to connect with the people of the Pacific during the Second World War. The writers and journalists covering the conflicts in the Pacific and Asia were responsible for creating in Australian society an image of the region which still survives today. Prue Torney-Parlicki's book, Somewhere in Asia: War, Journalism and Australia's Neighbours 1941 - 75, points out that the media often depicted a close relationship between the indigenous people and the Australian soldiers. However, Torney-Parlicki goes on to say that "media interest in the relationship between the Australians and the Papuans and Timorese who assisted them as carriers and guides offers no better example of the way such contact was used by commentators to characterise race relations".

On the foundation of this kind of coverage, the modern media finds it hard to unshackle itself from stereotypical images. Indeed, the question of image is a very pertinent one, given the capacity for the media to create and sustain images. Renowned Australian journalist, Graeme Dobell, who has long reported on Asian and Pacific affairs, argues that Australia is not accustomed to thinking of itself as a superpower, which leads to confusion and embarrassment on all sides. 
In a sense, then, Australia's role in the South Pacific is by default, rather than by design. According to Dobell: "Australia presides because of its geography, size and power, rather than through any particular set of policies or acts of will." This lack of policy and lack of will comes to the surface in the media coverage of the Pacific.

I want to take a little time to talk about the individuals who make up the media - the journalists. These are the people in a position to make a difference in the kind of reporting Australia sees and hears. As Pollock has said: "In the initial phases of a 'critical event', when happenings are ambiguous, opinions unformed, and policy amorphous, the personal attitudes of a handful of correspondents may exert influence of global proportions on the shaping of public and official responses" (Pollock, 1981: 8).

Australian coverage of the Pacific relies essentially on two different kinds of journalist. First, there is the foreign correspondent. These are people who are often based in the Pacific, living and working in the communities they are writing about. They invariably display a strong commitment to the future of the Pacific. In this group I would include people like Mary-Louise O'Callaghan of The Australian newspaper, the ABC's Sean Dorney and Richard Dinnen, and Mark Davis of SBS, though Davis resides in Australia. I would also have to give a special mention to New Zealand's David Robie, journalism coordinator at the University of the South Pacific, who has been writing about the Pacific with skill, passion and understanding for the last three decades.

Unfortunately, the high standards these people bring to their journalism is diluted, to a greater extent, because there is a lot of sub-standard journalism in the pool of Pacific reporting. The worst of it is conducted by commercial television and tabloid newspapers. Their kind of reporting is often carried out by what are sometimes referred to as "parachute journalists". They basically drop in to a country when there is trouble, file as many stories as will keep their editors happy, and as soon as the trouble is over they are gone again. In some cases, they return to their normal round back home, or if they are lucky there will be another crisis somewhere.

\section{Difficulties for in-depth reporting}

Jasper Hsu has pointed out that the growing trend to send reporters overseas only when necessary makes in-depth reporting difficult, if not impossible (Hsu 1982: 93). There are a range of difficulties that these reporters have to face. The biggest difference between the genuine foreign correspondents and the parachute 


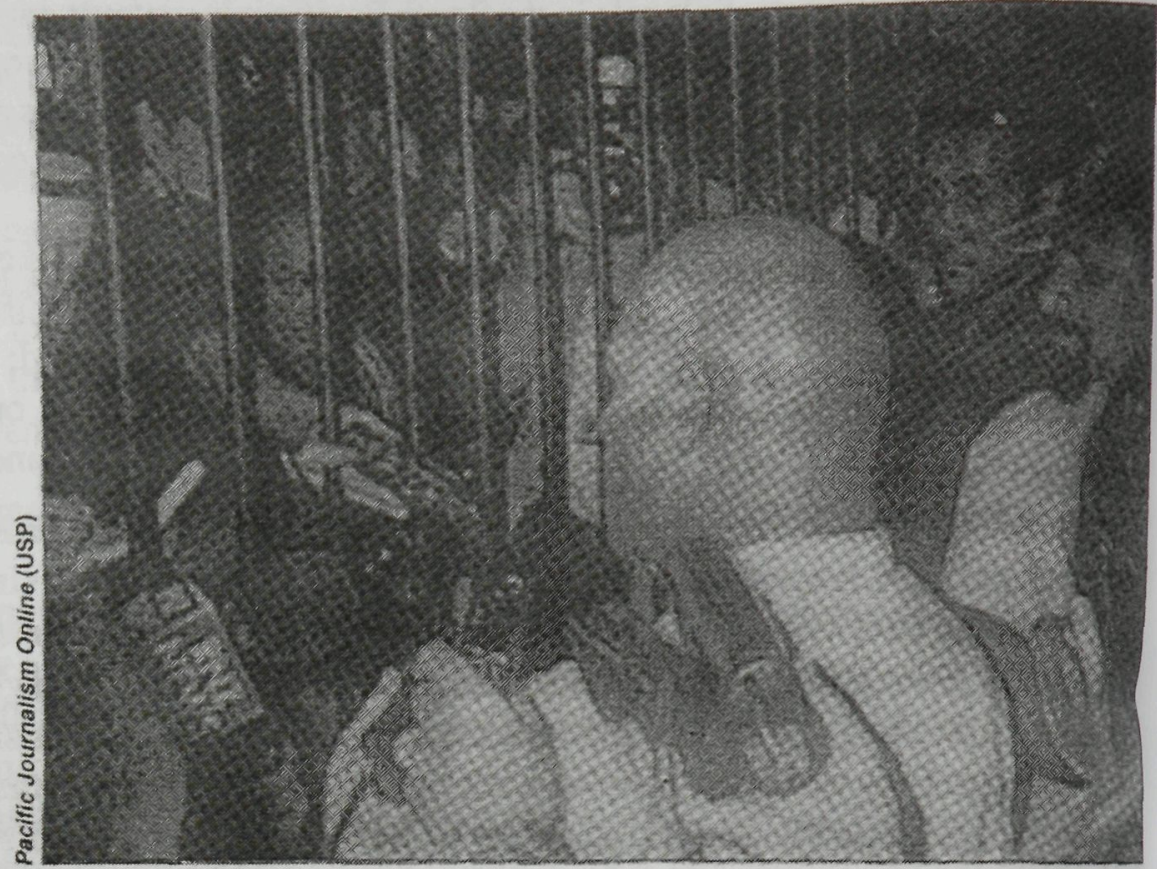

George Speight holds court: Was the media pack complicit?

journalists is how much time they have to think about the stories they are writing. The parachute journalists are working under the pressure of strict deadlines, on limited budgets, and in unusual or different circumstances. Operating under these conditions means there is no time for them to really consider what they are writing. As Tuchman suggests, the pressure of producing a newspaper or preparing a broadcast does not give journalists much time for "reflexive epistemological examination" (Tuchman, 1978). So their reports have to be simple, they have to be black and white and they have to give people - their audiences and their editors - what they are expecting. If there is a coup, there has to be soldiers and guns. If there is a tragedy, there has to be a body count. If there is a conflict, there has to be violence.

Another contributing factor is that the parachute journalists generally struggle for sources. So they go with what is available. For the media pack who covered the 2000 kidnapping of the Chaudhry government in Fiji, the best thing George Speight did was to hold a press conference every day. He was guaranteed coverage because the parachute journalists didn't have anywhere else to go. As a result, Speight got covered by reporters from Australia, Britain, France, Japan. New Zealand, Philippines, and the US. There has been considerable debate 
about whether this media pack was complicit in establishing Speight as a force to be reckoned with, but I will leave that for another time.

Of course, the other characteristic of parachute journalists is that they rarely return to the scene. That distance allows them the chance to escape from their mistakes. The distance also somehow increases the clarity of what they are saying. Audiences tend to trust reporters simply because they are there. The distance is also less scrutinising - it allows the facts to be less precise, or as precise as they need to be. My personal experience of this is when I was working in Moscow. If there was a Communist demonstration, the local Russian press would report there were 300 people, the local English language press would report there was 500 , and by the time it got to CNN there was 1000 people at the demonstration.

The further away you got, the bigger the crowd became. No doubt, you could argue that the increasing size of the crowd was serving the needs of the audience. The Russian community, who at the time were just coming to grips with caipitalism, didn't want to know about Communist demonstrations. The locial expats were a little more interested, because they liked the thrill of living in a former Communist country. And the CNN audience, most of all, needed to keep Cold War imagery alive. The different audiences framed things in different ways and the media responded to that.

The same thing happens in the Pacific. Australians frame things in particular ways, according to what they think, what they know and what they think they know. For example, Australian history has determined particular understanding of what the term indigenous means. In Australia, the indigenous people have been historically abused and neglected, have always been a small minority in the wider population, they have had to struggle for basic rights, they are at the centre of the serious issue of reconciliation, and they are often deficted very negatively in the media.

So when many Australians see the media apply the word indigenous to a group of people, regardless of where they are from, this is how they frame the concept. How they think, how they respond emotionally, how they react, is all determined by their concept of indigenous people in Australia. And the media only reinforces the notion. Narrowly defined concepts, generalisations and a lack of deeper explanation all continue to support these ideas. Thanks to the media, Australians generally don't know that indigenous people in Fiji are not in the same kind of position as indigenous Australians.

The same rule applies to the term migrant. For Australians, migrants are PACIFIC JOURNALISM REVIEW 7:1 200161 


\section{ANTHONY MASON}

determined by where they come from. In many ways, migrants are actually determined by where they have gone to. That a migrant in Fiji could be different from a migrant in Australia is not a concept which appears in the Australian press. Indeed, even the idea that there is a large migrant population in Fiji is something which would still surprise many Australians.

Part of the reason this kind of insubstantial coverage occurs is, I believe, related to how the media perceive their own potential to effec the audience. There is ongoing theoretical debate on the concept of media effects, but as one researcher, Elisabeth Noelle Neumann, has pointed out, the media tends to come down on the side of a limited effects theory. Her work revealed that effects research that showed no effect or a limited effect met with great'response from journalists and was publicly accorded scientific prestige. Research that showed a strong effect of the mass media, however, at best met with no response. By assuming a lack of power and a lack of ability to influence, the media is granted much less responsibility.

Interestingly enough, those outside the media do recognise their power. For example, various governments have shown that they believe the media has the potential to influence. The former foreign affairs minister of Australia, Gareth Evans, was famous for flying off to Kuala Lumpur to placate the Malaysians every time a newspaper criticised Dr Mahatir. Evans summed up this approach when he said that the media in Australia is both a vehicle reflecting foreign policy and a source of input to that process.

Equally, the actions of governments in the Pacific have demonstrated that they believe the media is influential. The most recent case is of Marc Neil-Jones, the publisher of the Vanuatu Trading Post, who had lived in that country for 11 years but was deported with two hours notice. Similarly, the banning of the Agence France-Presse reporter, Michael Field, from covering the 2000 South Pacific Forum in Kiribati, shows the lengths governments are prepared to go to in order to dictate to the media. Perhaps if the media were more willing to accept the power and the responsibility they have, then we would be more likely to have a better understanding of the Pacific.

\section{Why is it important?}

So why is it important that our media give us an improved understanding of the Pacific? Why does the media need to frame the Pacific in a different way? What is the value in it, for Australia?

Australia's connections, geographically, historically and economically, 62 PACIFIC JOURNALISM REVIEW 7:1 2001 
with the many nations of the Pacific have established a strong and distinct relationship. That relationship, both the positive and negative aspects of it, exists not only in the minds of the Australians and the people of the Pacific, but it also exists in the minds of the international community.

And as Graeme Dobell so succintly puts it: "If Australia fails in the South Pacific it would injure its rights to be a player in other key regions." This thinking is also reflected in a Foreign and Trade Policy White Paper, "In the National Interest", produced by the Federal Government in 1997. It states that: "Australia's international standing, especially in East Asia and in North Americal and Europe, is influenced by perceptions of how well Australia fulfills a leadership role in the Islands region."

It is unfortunate that this kind of argument is necessary in order to stimulate interest in the Pacific. It would be more preferable to argue that Australia should be interested in the Pacific because the people of the region can offer us immense and unique benefits, improving our cultural, artistic and social selves greatly. But as I said, that is not enough. The artists and writers and painters and poets will only bear fruit if they can convince the accountants and businessmen that there is something in it for them.

\section{How can the media help?}

So how can the media help? How can they play a role in building this better relationship? First of all, the media has to stop looking at the Pacific as a potential war zone. The tone and manner of the media approach to the recent conflicts in the Pacific only reinforces what Greg Fry calls

a doomsday mentality in Australian thinking about the Pacific. Partly, this springs from the very tenets of journalism itself, where the idea of conflict is not really accepted until people are being physically harmed. Australian journalists have to see that their treatment of the Pacific needs 10 be more generous, and less stcreotypical.

Of course, it is not all down to the journalists. It is also down to the media organisations. In researching the media in the Pacific, it soon became apparent that you could count the genuine Pacific correspondents on one hand. The media organisations have to support more Pacific correspondents. As Mary-Louise $O^{\prime}$ Callaghan said at a recent Canberra conference on preventing coups, she was desperate for some competition. 


\section{ANTHONY MASON}

"Send more good people," she said.

Overall, though, the most apparent change the media could make is to be more self-critical about their reporting. According to Merrill, journalists are paradoxical creatures, who want to be individual but seek a sense of unity, who perceive themselves as social critics but take criticism badly (Merrill 1974: 17). It is time the media realised that there is room for improvement and it is up to them to better themselves, for all our sake.

\section{Bibliography:}

Fry, Greg (1997), "Framing the Islands: Knowledge and power in changing Australian images of the South Pacific." The Contemporary Pacific, Vol 9, Fall.

Hsu, J. (1982), "Global News Flow - Problems: A Journalist's Perspective." Internu. tional Perspectives on News. L. E. Atwood, Bullion, Stuart J, Murphy, Sharon M. Carbondale. Illinois: Southern Illinois University Press: pp 91-95.

Merrill, J. C. (1974), The Imperative of Freedom - A Philosophy of Journalisic Autonomy. New York: Hastings House.

Pollock, J. C. (1981), The politics of crisis reporting. New York, Praeger Publishers. Torney-Parlicki, P. (2000). Somewhere in Asia - War, Journalism and Australia's Neighbours 1941-75. Sydney, UNSW Press.

Thomson. Peter (1999), Kava in the Blood. Tandem Press, Auckland, NZ.

[] Anthony Mason is a Canberra journalist who researches Pacific media issues and is doing a master's degree on the topic. He originally presented this article as a paper on Australian media at the "Resistance and Reconciliation: Writing in the Commonwealth" at the conference, the 12th Triennial Conference of the Association for Commonwealth Literature, at Canberra University, 9-14 July 2001. a.mason@student.canberra.edu.au 